Modern Asian Studies 52, 3 (2018) pp. 784-814. (C) Cambridge University Press 2018 doi:10.1017/Soo26749X16000445

\title{
Public Authority Under Sovereign Encroachment: Leadership in two villages during Sri Lanka's war*
}

\author{
BART KLEM \\ School of Social and Political Sciences, University of Melbourne \\ Email:bklem@unimelb.edu.au \\ SIDHARTHAN MAUNAGURU \\ South Asian Studies Programme, National University of Singapore \\ Email:sasms@nus.edu.sg
}

\begin{abstract}
In this article, we compare two kinds of public authority under conditions of civil war. We study two villages in eastern Sri Lanka, both of which came under LTTE rule during the 1990 and 2ooos. The first case study describes a rural development society, which was co-opted by the LTTE to rule the village. The second describes the leaders of a Hindu temple, who defied LTTE attempts to settle temple-related conflicts. Conceptually, we draw on the notion of the public sphere as a space of encounter between the rulers and the ruled. This perspective helps us come to grips with the convoluted political landscape of war. Our two case studies suggest that public authority and sovereignty are mutually constituted. We argue that both forms of power are reworked in the encounter with the public sphere. A sovereign aspirant like the LTTE does not simply impose itself on

* The alphabetical listing of our names reflects our equal authorship of this article. We would like to thank the two anonymous reviewers for their constructive comments. We also gratefully acknowledge Amanda Gilbertson, Atreyee Sen, and Bert Sukyens for helpful feedback on an earlier draft of this article. Thanks to Shahul Hasbullah, Benedikt Korf, and Jonathan Spencer for the collaborative work that has informed this article. We are also grateful to all those who helped us during fieldwork, with suggestions and translation or by sparing their time to talk to us. Bart Klem gratefully acknowledges the financial support of the Swiss National Science Foundation (SNF) for the fieldwork (grant numbers PDFMP1-123181/1 and 100017_149183). Sidharthan Maunaguru acknowledges the start-up grant provided by the National University of Singapore and the Newton Fellowship funded by the British Academy and the Royal Society, both of which supported the research.
\end{abstract}


society, it encroaches on it. This involves contingent efforts of reigning in other forms of public authority, some of which are more defiant than others. Conversely, public authority not only derives validity from sovereign endorsement, but from contestations around sovereignty as well.

\section{Introduction}

In this article, we discuss the eventuation of public authority under conditions of civil war. How is public authority sustained and reinvented when the foundations of public order are violently contested and reconstituted? More specifically, we compare two specific kinds of public authority-a village development council and the leadership of a Hindu temple-in two villages that came to be ruled by the Tamil insurgency during Sri Lanka's ethno-political war.

We explore this question by drawing on South Asian literature on the public sphere as a zone of encounter. This literature holds that the constitution of the public, the constellation of authority, and the larger framework of sovereign order are not simply imposed but worked out through the public sphere. ${ }^{1}$ Much of this literature is historical-it explores South Asia's contingent process of defining and redefining notions of community, legitimacy, and legality through court proceedings, assertions of leadership, and other forms of public conduct. This conceptual angle on the historical evolution of political consciousness and sovereign order is helpful, we find, in coming to grips with the convoluted political landscape of Sri Lanka's civil war. It takes us away from an exclusively top-down perspective of sovereign imposition-coercive power capable of invoking, erasing, or endorsing supposedly softer forms of public authority. Instead, it focuses on the convoluted ways in which sovereign rule and public authority are being articulated in societies at war.

Public authority tends to be linked-directly or indirectly-to the state, as the 'great enframer' of society. ${ }^{2}$ Insurgent movements like the Liberation Tigers of Tamil Eelam (LTTE) challenge the state order

${ }^{1}$ Arjun Appadurai (1996) Modernity at large: Cultural dimensions of globalization. Minneapolis: University of Minnesota Press; Arjun Appadurai and Carol A. Breckenridge (1998) 'Why public culture?', Public Culture Bulletin, 1 (1), pp. 5-9; Francis Cody (2011) 'Publics and politics', Annual Review of Anthropology, 40, pp. 3752; David Gilmartin (2015) 'Rethinking the public through the lens of sovereignty', South Asia: Journal of South Asian Studies, 38 (3), pp. 37 1-386.

${ }^{2}$ Thomas B. Hansen and Finn Stepputat (eds) (2001) States of imagination: Ethnographic explorations of the post-colonial state. Durham: Duke University Press, p. 27. 
and present themselves as sovereign aspirants in their own right. The perspective of the public sphere as a zone of encounter helps us to unravel how public authority evolves when its frame of reference-the sovereign order of the state-is challenged, erased, or supplanted by a rival claim to sovereignty. How, in short, is public authority maintained or reconstituted in an environment where an insurgent movement vies to replace the state?

Building on earlier work, ${ }^{3}$ we explore how the LTTE tried to assert hegemony over community-level institutions in two villages in eastern Sri Lanka. We conducted fieldwork in the early 2000 s when the insurgent LTTE controlled parts of the region, and complement this material with retrospective interviews conducted after the 2009 defeat of the LTTE. Both case studies represent quite different forms of public authority. The first looks at the rural development society (RDS) of a Veddah village; the second discusses the Hindu temple leadership of a mixed-caste Tamil village. In both cases, the LTTE aspired to establish itself as a sovereign formation. It sought to co-opt village institutions to assert its rulership, to present itself as the referent of all authority, and to redefine-and discipline-the public as the Tamil nation. In both villages, the community was profoundly transformed by these efforts, but at the same time, the movement's assertion of sovereignty was not all-encompassing. It also involved deliberately blurred boundaries, subtle forms of pushback, and compromised rule.

Interestingly, the LTTE's ability to domesticate the two institutions varied significantly. The LTTE took firm control over the RDS, enabling the insurgents to rule by proxy and hold sway over the development resources that continued to trickle into the area. Conversely, the LTTE's ability to preside over Hindu temple affairs was much more constrained. Some of its commands were in fact openly defied. We attribute these differences to the nature of both institutions. In short, an RDS is supposed to act as an interface between

\footnotetext{
${ }^{3}$ Bart Klem (2012) 'In the eye of the storm: Sri Lanka's front-line civil servants in transition', Development and Change, 43 (3), pp. 695-717; Bart Klem and Sidharthan Maunaguru (2017) 'Insurgent rule as sovereign mimicry and mutation: Governance, kingship and violence in civil wars', Comparative Studies in Society and History, 59 (3), pp. 629-656; Sidharthan Maunaguru (under review) 'Vulnerable sovereignty: Sovereign deities and Tigers' politics in Sri Lanka'; Sidharthan Maunaguru and Jonathan Spencer (2013) 'Tigers, temples, and the remaking of Tamil society: Report from the field', Religion and Society, 3 (1), pp. 169-176; Jonathan Spencer, Jonathan Goodhand, Shahul Hasbullah, Bart Klem, Benedikt Korf and Kalinga Tudor Silva (2015) Checkpoint, temple, church and mosque: A collaborative ethnography of war and peace. London: Pluto.
} 
PUBLIC AUTHORITY UNDER SOVEREIGN ENGROAGHMENT 787 the community and the state. When the LTTE presented itself as a replacement of the state, the RDS's authority and public essentially yielded. Hindu temples are a very different kind of institution. They are constituted on an intra-Tamil canvas of castes and clans, and they invoke a kind of public authority that is sourced in deities, in a world beyond the grasp of the LTTE. Attempts to subjugate the temples thus conjured up all kinds of challenges and contradictions for a sovereign aspirant like the LTTE.

Building on these insights, we will conclude with a broader point about the mutually constitutive nature of public authority and sovereignty. Both, we argue, are reworked in the encounter with the public sphere. Sovereignty does not simply impose itself on society, it encroaches on it. And public authority not only derives validity from sovereign endorsement, but from contestations around sovereignty as well.

\section{Public authority in a contested environment}

As elaborated in the Introduction to this issue, ${ }^{4}$ we understand public authority as a relational form of power that hinges on perceived legitimacy among the subjects of authority, and thus wields influence on the basis of a measure of voluntary compliance. ${ }^{5}$ Public authority is typically embedded in some kind of institutional architecture. There are two important preliminary points that we need to raise in this connection. First, public authority tends to pertain both to an agent (the authority figure) and an institution, which connects this figure to a demarcated constituency, a register of legitimacy, and the wider institutional landscape. The institutional arrangement provides public authority with a formal or informal mandate that delineates some expectations of conduct. But given that part of the authority is vested in the agent, there is often scope to reframe the institution or to simply act beyond, or even in contradiction to, this mandate. Such conduct in turn may affect the way institutions are enacted and

\footnotetext{
${ }^{4}$ Bart Klem and Bert Suykens, 'The politics of order and disturbance: Public authority, sovereignty, and violent contestation in South Asia' in this special issue.

${ }^{5}$ Muthiah Alagappa (1995) Political legitimacy in Southeast Asia: The quest for moral authority. Stanford: Stanford University Press; Christian Lund (2006) 'Twilight institutions: Public authority and local politics in Africa', Development and Change, 37 (4), pp. 685-705; Thomas Sikor and Christian Lund (2009) 'Access and property: A question of power and authority', Development and Change, 40 (1), pp. 1-22.
} 
understood. ${ }^{6}$ Examples are not hard to come by. Politicians derive legitimacy from the office of the legislature, but in some contexts, not least in South Asia, they are renowned for bending (or breaking) the rules of that same structure. ${ }^{7}$ Similarly, civil servants tend to propagate a repertoire of codified rules and circulars, on the one hand, while, on the other, they may use their position to blur the boundaries they are supposed to uphold. Such practices may have a significant level of legitimacy, particularly when the public perceives them as necessary to make things work. ${ }^{8}$

Secondly, public authority and the institutions in which it is steeped tend to be subject to state endorsement, and they often derive a level of recognition and legitimacy from this. Conversely, state order often leans quite heavily on the institutional extensions beyond the state proper. ${ }^{9}$ Public authority, to use Lund's phrase, is often 'conjugated with the idea of a state'. ${ }^{10}$ But what is the underlying grammar of these 'conjugations'? That is: how are the interconnections between specific forms of public authority and the larger political order worked out? And does this translate to a different language? That is: what happens to these conjugations of authority when that 'idea of the state' is challenged, changed, or supplanted by a different one?

Central to the relationship between public authority and the state is the conception of the term 'public', a heavily debated term in South Asia and beyond. ${ }^{11}$ Interestingly, as David Gilmartin points

${ }^{6}$ Mary Douglas (1986) How institutions think. Syracuse: Syracuse University Press; Sally Falk Moore (1978) Law as process. London: Routledge; Lund, 'Twilight institutions'.

${ }^{7}$ For discussion on these dynamics in the context of Punjab, see Nicolas Martin, 'Corruption and factionalism in contemporary Punjab: An ethnographic account from rural Malwa' in this special issue.

${ }^{8}$ For examples, see two of the contributions on Nepal in this special issue: Sarah Byrne, "From our side rules are followed": Authorizing bureaucracy in Nepal's "permanent transition"”; Andrea J. Nightingale, Anil Bhatterai, Hemant R. Ojha, Tulasi Sigdel and Katharine N. Rankin, 'Fragmented public authority and state un/making in the "new" Republic of Nepal'.

${ }^{9}$ Clifford Geertz (1980) Negara: The theatre state in nineteenth century Bali. Princeton: Princeton University Press; Hansen and Stepputat, States of imagination.

${ }^{10}$ Lund, 'Twilight institutions', p. 686, emphasis in original.

${ }^{11}$ Appadurai, Modernity at large; Cody, 'Publics and politics'; Jean B. Elshtain (1981) Public man, private women: Women in social political thoughts. Princeton: Princeton University Press; Jürgen Habermas (1989 [1962]) Structural transformation of the public sphere: An inquiry into a category of bourgeois society. Cambridge: MIT Press; Webb Keane (2003) 'Public speaking: On Indonesian as a language of the nation', Public Culture, 15 (3), pp. 503-530; Bruno Latour and Peter Weibel (eds) (2005) Making things public: Atmosphere of democracy. Cambridge: MIT Press; Arvind Rajagopal (2001) Politics after 

out, this concept may denote the state itself (e.g. the public sector, public policy), a community standing apart from the state (e.g. public opinion), or the zone of interaction between the two (e.g. the public sphere, public space). ${ }^{12}$ Building on the work of Appadurai and Breckenridge, ${ }^{13}$ Gilmartin's analysis of court proceedings and political discourse in India posits that the third meaning-the public sphere as a zone of interaction-is central to understanding the historical evolution of India's political order. Sovereign rule was not simply vested in the idea of the Indian populace as the public. Rather, the public sphere was the stage on which notions of rule evolved in colonial and post-colonial times, as had been the case prior to the arrival of Europeans. It was through the public sphere of court proceedings that older forms of kingship were fragmented and the internal politics of aristocratic families became exposed. It was where religious leaders were subjected to allegations of corruption, thus enacting a form of public morality, through which an overarching communitasa collective that transcends everyday divisions-became thinkable. Finally, Gandhi's performance of denunciation and sacrifice gained traction through the public sphere. In sum, the post-colonial sovereign order-and the tapestry of public authority operating within itwas not simply a 'top-down' colonial imposition, nor a 'bottomup' invocation of popular sovereignty, but a much more contingent articulation that emerged through encounters in the public sphere.

The irresolvable contradiction of the public as quintessentially united and divided is an immutable constant throughout this historical evolution, Gilmartin holds. He connects this central dilemma of political community to the sovereign conundrum, a common feature of both European ${ }^{14}$ and South Asian political history. ${ }^{15}$ On the one hand, sovereignty needs to be deeply connected to the mundane and political world, thus embodying society as a fallible collective, troubled by divisions and conflict. But at the same time, the sovereign figure must also be elevated above the discord to embody the unity of community.

television: Hindu nationalism and the reshaping of the public in India. Cambridge: Cambridge University Press; Charles Taylor (2004) Modern social imaginaries. Durham: Duke University Press.

${ }^{12}$ Gilmartin, 'Rethinking the public'.

${ }_{13}$ Appadurai and Breckenridge, 'Why public culture?'.

${ }^{14}$ Ernst Kantorowicz (1997 [1957]) The king's two bodies: A study in mediaeval political theology. Princeton: Princeton University Press.

${ }^{15} \mathrm{~J}$. C. Heesterman $(1985)$ The inner conflict of tradition: Essays in Indian ritual, kingship and society. Chicago: University of Chicago Press. 
In short, the public sphere is a space of encounter between the rulers and the ruled, where the irresolvable tensions of the ruled (who are unavoidably united and divided) and those of the rulers (who are both steeped in the community and elevated above it) are articulated.

This idea of the public sphere as a zone of encounter should not be trapped in an overly schematic binary of 'the state' and 'society'. In most contexts, it would be inadequate to suggest there is one form of order. As the literature on legal pluralism suggests, most societies are characterized by multiple forms of order, and there is typically a level of convergence and conflict between them. ${ }^{16}$ The legal system of a sovereign state often coexists with legal customs associated with tradition, ethnicity, or religion. These intersections have spawned some intense academic debate, particularly when it concerns the juxtaposition of the religious and the political spheres. Arguing against the secular reflex of treating these two as oppositional entities, many scholars have scrutinized the interactions between political and religious discourse. ${ }^{17}$ Clearly, it is not uncommon to observe some form of slippage, borrowing, or mimicry between different registers of order. Many political regimes adopt symbols and expressions of power from the religious sphere in their quest for acceptance.

Given the plurality of orders, the public sphere, as a zone of encounter, tends to be rather multifarious. The plurality discussed in legal pluralism literature typically denotes forms of authority that exist in parallel or in partial overlap. There may be frictions between them, and they may challenge the state, but they do not seek to supplant the state. They may shrug off the sovereign logic of the state to some extent, but they do not subvert it altogether. This is substantially different in contexts where the overarching sovereign order is contested head on, such as the one studied in this article. Most violent insurgencies act in pursuit of a fundamentally different order, be it a

\footnotetext{
${ }^{16}$ Franz von Benda-Beckmann and Keebet von Benda-Beckmann (2013) Political and legal transformations of an Indonesian polity: The nagari from colonisation to decentralisation. Cambridge: Cambridge University Press.

${ }^{17}$ Talal Asad (1993) Genealogies of religion: Discipline and reasons of power in Christianity and Islam. Baltimore: Johns Hopkins University Press; Nicholas Dirks (1987) The hollow crown: Ethnohistory of an Indian kingdom. Cambridge: Cambridge University Press; Sidharthan Maunaguru (2014) 'Sri Lankan Hindu temples and politics: Contesting spaces of politics and sovereign deities'. Paper presented at the American Anthropological Association Annual Conference; William Sax (2000) 'Conquering the quarters: Religion and politics in Hinduism', International Journal of Hindu Studies, 4 (1), pp. 3-6o; Peter van der Veer (2001) Imperial encounters: Religion, nation, and empire. Princeton: Princeton University Press.
} 
separate state, a revolutionized state, a religiously founded state, or otherwise. They are not simply vying for a form of public authority; they are sovereign aspirants. The public sphere as a zone of encounter thus becomes a much more troublesome space where definitions of the public and claims to sovereign rule are violently contested.

Civil wars are obviously not just a military confrontation between the state, insurgents, and/or other players. They are characterized by competitive projects of making, sustaining, co-opting, and redefining public order. As aspiring sovereigns, insurgents mimic state conduct by engaging in a social contract with their subject population. ${ }^{18}$ Clearly, conceptualizing these insurgent projects of rule as a form of governance should not blind us to the deeply coercive backbone of insurgencies. But at the same time, it is important to recognize that insurgent rule is not exclusively about violence and coercion. As denoted in the term 'sovereign encroachment' in the title of this article, this process unfolds in the public sphere: it involves the subtle and gradual redrawing of boundaries, co-option of institutions, and redefining of the public. Rather than simply being erased or subdued by the violent exchanges between belligerents competing for state power, public authority may thus play quite a substantive role in insurgent attempts to encroach on the sovereign order, and in state efforts to withstand this encroachment.

\section{Contested order in eastern Sri Lanka}

Sri Lanka emerged relatively unscathed from colonial rule with a broad array of state institutions reaching all the way to the village level and a

\footnotetext{
${ }^{18}$ Ana Arjona (2014) 'Wartime institutions: A research agenda', Journal of Conflict Resolution, 58, pp. 1390-1418; Ana Arjona, Nelson Kasfir and Zachariah Mampilly (eds) $(2015)$ Rebel governance in civil war. Cambridge: Cambridge University Press; Nina Caspersen (2012) Unrecognized states: The struggle for sovereignty in the modern international system. Cambridge: Polity Press; Thomas B. Hansen and Finn Stepputat (eds) (2005) Sovereign bodies: Citizens, migrants and states in the postcolonial world. Princeton: Princeton University Press; Stathis Kalyvas (2006) The logic of civil war. Cambridge: Cambridge University Press; Klem and Maunaguru, 'Insurgent rule as sovereign mimicry and mutation'; Zachariah Mampilly (2011) Rebel rulers: Insurgent governance and civilian life during war. Ithaca and London: Cornell University Press; Paul Staniland (2012) 'Organizing insurgency: Networks, resources and rebellion in South Asia', International Security, 37 (1), pp. 142-177; Jeremy Weinstein (2007) Inside rebellion: The politics of insurgent violence. Cambridge: Cambridge University Press; Elisabeth Wood (2008) 'The social processes of civil war: The wartime transformation of social networks', Annual Review of Political Science, 1 1, pp. 539-561.
} 
functioning democracy. The colonial encounter had absorbed localized customs, legal codes, community leaders, and religious institutions into a unified political structure. ${ }^{19}$ The Sri Lankan case represents a highly institutionalized state with a meticulous apparatus that percolates society. At the same time, the nature of that state was the basis of the country's burdensome history of conflict, with major leftist uprisings ${ }^{20}$ and a protracted Tamil separatist conflict. The latter escalated into a full-fledged civil war in the 1980 os and the LTTE emerged as the main military challenger to the government. ${ }^{21}$

In the course of the 1990s, a checkerboard, militarized geography emerged in Sri Lanka's northeast. The LTTE had transformed from boys on bicycles staging hit-and-run attacks to a military force capable of sustained control over territory and people. It gradually started to establish administrative, judicial, and financial institutions that resembled a state-like apparatus. Some of these institutions were new inventions, many were mimicked from elsewhere, and some were plainly co-opted. As discussed elsewhere in this volume ${ }^{22}$ and in our own work, ${ }^{23}$ the movement adopted and imitated institutions from the Sri Lankan state: offices, uniforms, stamps, archives, banks, and village development societies. Similarly, it adopted and imitated institutional

${ }^{19}$ Kingsley De Silva (2005) A history of Sri Lanka. Colombo: Vijitha Yapa Publications; Nira Wickramasinghe (2006) Sri Lanka in the modern age: A history of contested identities. London: Hurst.

${ }^{20}$ More specifically, the Janatha Vimukthi Peramuna (JVP), a leftist revolutionary youth movement with elements of Sinhala ethno-nationalism. The JVP staged two highly destabilizing uprisings in the 1970 os and 1980s. See Mick Moore (1993) 'Thoroughly modern revolutionaries: The JVP in Sri Lanka', Modern Asian Studies, 27 (3), pp. 593-642.

21 Neloufer De Mel (2007) Militarizing Sri Lanka: Popular culture, memory and narrative in the armed conflict. London: Sage; Jonathan Goodhand, Jonathan Spencer and Benedikt Korf (eds) (201 1) Conflict and peacebuilding in Sri Lanka: Caught in the peace trap? London and New York: Routledge; Ketesh Loganathan (1996) Sri Lanka, lost opportunities: Past attempts at resolving ethnic conflict. Colombo: University of Colombo; Mick Moore (1985) The state and peasant politics in Sri Lanka. Cambridge: Cambridge University Press; Kumar Rupesinghe (ed.) (2006) Negotiating peace in Sri Lanka: Efforts, failures and lessons. Colombo: Foundation for Co-existence; Sharika Thiranagama (2011) In my mother's house: Civil war in Sri Lanka. Philadelphia: University of Pennsylvania Press; Jayadeva Uyangoda (2007) Ethnic conflict in Sri Lanka: Changing dynamics, Policy Studies 32. Washington DC: East-West Center; J. Uyangoda (2011) 'Travails of state reform in the context of protracted civil war in Sri Lanka', in Kristian Stokke and Jayadeva Uyangoda (eds) Liberal peace in question: Politics of state and market reform in Sri Lanka. London: Anthem Press, pp. 46-75; Wickramasinghe, Sri Lanka in the Modern Age.

${ }^{22}$ Niels Terpstra and Georg Frerks, 'Governance practices and symbolism: De facto sovereignty and public authority in "Tigerland" in this special issue.

${ }^{23}$ Klem and Maunaguru, 'Insurgent rule as sovereign mimicry and mutation'. 
forms from the religious sphere, thus producing an elaborate array of ceremonies, rituals around sacrifice, glorification of the movement, and deification of its leader Prabhakaran as an immortal divine king. The movement sought to establish its supremacy by bringing together all societal forms of leadership and organization under its tutelage. It subjected Tamil society to a strict regime of loyalty, taxation, and recruitment, and forced challengers to its authority into compliance, hiding, or refuge. ${ }^{24}$

While the movement succeeded to the extent that it was able to consolidate its rule in some areas-most saliently in the northern region known as the Vanni during the 2002-2005 period when the ceasefire eased military action-it is important to add that this rule was always contingent and had rough edges. The government military continued to control major parts of the northeast and there were many 'grey areas' (places where the LTTE had only partial influence). This was particularly clear in the eastern region, ${ }^{25}$ which is the focus of this article. The east coast has a mixed population of Muslims, Tamils, and Sinhalese as well as smaller communities like Veddahs and Burghers living in relatively homogeneous pockets. This complicated the assertion of military control. Both armed parties focused their primary political and military energy on the Tamil heartland in the north and treated the east as a subsidiary front. This resulted in a political landscape where the government military controlled the two main towns-Trincomalee and Batticaloa-as well as the Sinhala- and Muslim-dominated areas, while the LTTE assumed control over those rural areas where Tamil settlements prevailed.

Both villages studied in this article are rural communities in Tamildominated areas where the LTTE established a firm and enduring grip on society. The village in Case study 1 , which we will call Adivasipuram, is inhabited by Veddahs, who comprise a fraction of the

\footnotetext{
${ }^{24}$ See also: Mampilly, Rebel rulers; Rohini Mohan (2014) The seasons of trouble: Life amid the ruins of Sri Lanka's civil war. London: Verso; Muttukrishna Sarvananthan (2007) 'In pursuit of a mythical state of Tamil Eelam: A rejoinder to Kristian Stokke', Third World Quarterly, 28 (6), pp. 1185-1195; Kristian Stokke (2006) 'Building the Tamil Eelam state: Emerging state institutions and forms of governance in LTTE-controlled areas in Sri Lanka', Third World Quarterly, 27 (6), pp. $1021-1040$; Thiranagama, In my mother's house.

${ }^{25}$ Klem, 'In the eye of the storm'; Benedikt Korf (2004) 'War, livelihoods and vulnerability in Sri Lanka', Development and Change, 35 (2), pp. 275-295; Benedikt Korf, Michelle Engeler and Tobias Hagmann (2010) 'The geography of warscape', Third World Quarterly, $3^{1}$ (3), pp. 385-399; Terpstra and Frerks, 'Governance practices and symbolism'.
} 
national population and are often labelled as the island's aboriginals. ${ }^{26}$ Adivasipuram's inhabitants nevertheless see themselves as part of the Tamil nation and the LTTE treated them as such. Case study 2 concerns a mixed-caste village, which we will call Mukkuvarpattu, with a long-established history in which the local temples play a significant role. Many people in the community own land and were able to sustain some kind of livelihood despite the difficulties of the war. Both villages lived through the turbulent years of the 1980 s with multiple Tamil militias vying for power, and then came under LTTE control more or less uninterruptedly from the early 1990s until 2006-2007 when the government military drove the LTTE out of the east (followed by the 2009 defeat of the insurgency in the north).

\section{Case study 1: rural development society in Adivasipuram}

Adivasipuram is a small rural settlement of agricultural day labourers, living along both sides of a dirt road. There is a small Hindu temple, but Christianity has been on the rise in recent years with a range of evangelical movements running church services. The people were settled here under the patronage of a local district politician in the decade before the war escalated. Many of their relations live just a few kilometres away, in the area they inhabited before Adivasipuram was created. The village is surrounded by scrub, but there are paddy fields within walking distance. Historically, the people earn their living as carpenters or agricultural labourers. Others go fishing; some collect fruits, honey, or game from the forest. The village continues to be poor, though post-war developments have had a remarkable impact. Until recently, only a few had a modest brick house. Their neighbours lived in huts of wooden poles and dried palm tree leaves ('cadjan'). Adivasipuram lies in a Tamil-dominated area, the people have ample connections with neighbouring Tamil villages, they speak the Tamil language, and they consider themselves to be part of the Tamil cultural and political community. At the same time, however, they refer to themselves as 'Adivasi'. Government administrators continue to describe them as Veddahs, a category separate from other ethnic

\footnotetext{
${ }^{26}$ The 1953 census estimated the Veddahs at only 1 , ooo (out of a population of 8 million); subsequent censuses have grouped them under 'Others' along with other small groups. Given the fuzziness involved in demarcating the Veddahs and a level of fluidity in their self-definition, these numbers have limited value.
} 
groups. Yet, the people in Adivasipuram see no contradiction between their Veddah classification and their Tamil affiliation.

Contrary to the colonial idea of Veddahs as the indigenous population of Sri Lanka, it is unfounded to think of them as a separate race. Rather, as James Brow points out, they are best understood as a 'variga' (kind), somewhere between a caste group and an ethnic group at the fringes of both the Tamil and the Sinhala community. ${ }^{27}$ It would be misleading to call them forest dwellers, but it is true that they have always been peripheral in social, economic, and political terms. Brow's work provides a constructive vantage point for a study of Adivasipuram. His work on the Veddah village of Kukulewa (in the Sinhala-dominated district of Anuradhapura) describes the increased intrusion of the state into the community throughout the late $197 \mathrm{Os}$ and 1980 s. The government became an increasingly visible supplier of development through the provision of dedicated housing programmes and agricultural livelihood support. This role of a benefactor went hand in hand with the ambition of 'inviting the masses into history', thus nurturing an awareness of its position in the larger historical trajectory of the nation-a 'nation of villages'. ${ }^{28}$ Both development and nationalism served as a platform for competitive party politics. As elsewhere in the country, a rural development society (RDS) played a major role in this process. ${ }^{29}$ This elected village council served as an outreach mechanism of the state, a clearing house for the distribution of patronage, a forum for articulating community leadership, and a political tentacle for competing party networks. The creation of RDSs was, to use Gilmartin's term, an intervention in the public sphere that made new connections between the state and a peripheral part of society. It made the village more legible to the state and vice versa. And this process rendered the peasant public into citizens, who came under

${ }^{27}$ James B. Brow (1974) 'Veddah villages: A study of the history and social structure of Veddah communities in Anuradhapura District, Ceylon', PhD thesis, University of Washington; James B. Brow (1996) Demons and development: The struggle for community in a Sri Lankan village. Tucson: University of Arizona Press.

${ }^{28}$ See also: Michael Woost (1994) 'Developing a nation of villages: Rural community as state formation in Sri Lanka', Critique of Anthropology, 14 (1), pp. 77-95.

${ }^{29}$ For similar observations in the context of Nepal, see the contributions of Byrne and Nightingale et al. in this special issue, specifically with regard to the role of village development committees (VDCs) and their positioning between state and community, buffeted by the forces of patronage politics and Maoist insurgency: Byrne, "From our side"'; Nightingale et al., 'Fragmented public authority'. 
increased pressure to 'show their colours' in a competitive political environment. ${ }^{30}$

Brow identifies several fascinating paradoxes that emerge from these developments. First, there is the contradiction between the celebration of traditional values and a glorified past and the simultaneous shift towards commercialized agriculture and a capitalist economy. Secondly, it is interesting that the discourse of nationalism—adamant about celebrating unity—should be propelled by the forces of party politics, which thrive on factionalism and rivalry. And thirdly, it is peculiar that the Veddahs, whose genealogical role in the Sinhala cultural repertoire is to serve as a 'savage outside' which helps define Sinhala civilization, are themselves incorporated into that Sinhala civilization. These observations become all the more interesting when we move from Kukulewa back to Adivasipuram in the east-a mere 1 oo kilometres_-to find a similar village of Veddahs being incorporated into the Tamil (rather than Sinhala) nation, ruled by the LTTE (rather than the government). This spawns some quite similar dynamics that play out in quite a different way.

I (Bart Klem being the ' $I$ ' in this case study) first encountered Adivasipuram over a period of several months in 2000/2001, when I studied policy dilemmas of non-governmental organizations (NGOs) working in the war zone. The village was firmly in LTTE territory and the military was reluctant to allow foreigners access, but I managed to get permission to stay overnight, thus enabling me to make trips of two days at a time. I looked at the basic micro-finance projects that international NGOs were providing: revolving loans for goat rearing, gardening, and so on. In accordance with the participatory mode of development interventions, the projects were implemented by the village's rural development society.

Getting to the village involved crossing some important boundaries. Throughout what the government called a 'cleared area', there were regular army checkpoints and patrols. Only the final checkpoint had an actual barrier, followed by a small stretch of no-man's land. Beyond that, the LTTE was known to be in control, but one would rarely see them. There were no checkpoints in LTTE territory and cadres were a rare sight. There was, however, an LTTE office-a residential house with a few armed guards-where outsiders like myself would

\footnotetext{
${ }^{30}$ For a discussion of the interconnections between elections and community in contemporary Sri Lanka, see Bart Klem (2015) 'Showing one's colours: The political work of elections in post-war Sri Lanka', Modern Asian Studies, 49 (4), pp. 1091-1 121.
} 
broker access to the area. I never actually saw a cadre in uniform in Adivasipuram itself, but I soon found out that the lack of a visible presence was no sign of a laissez-faire attitude. While interviewing the RDS leadership about project details, it became clear they did not always have an overview of the accounts and were not very autonomous in managing their affairs. They regularly cycled back and forth to the neighbouring town, to receive instructions or seek endorsement from the LTTE office and to access their funds, which were kept in an LTTE bank.

As I passed from household to household to conduct my sample of interviews, it turned out the RDS leaders had been involved in more than just administrating aid projects. They had also run 'shramadanas' in the past. While this is a common civil society activity whereby the community joins together to clean up the village, a road, or clear some bushes, it dawned on me that the image of mobilizing youngsters with spades and hoes, putting their physical labour in the service of a common cause was not that far removed from the LTTE propaganda of youngsters joining hands for the Tamil nation and its liberation struggle. This idea took firmer root when I heard that the same group of people had been involved in enforcing particular rules, such as banning alcohol, a common practice throughout LTTE territory. ${ }^{31}$ Punishments could be rather crude; some people recounted the use of physical force and people being placed in a plot surrounded by barbed wire. In people's recollection of these practices, there was sometimes some slippage between the RDS and the LTTE. This confused me, as they were two rather different entities in my mind. It left me wondering whether this ambiguity was in some ways the point. This was confirmed when people told me that almost all of the youngsters who had been active in these kinds of shramadana and compliance activities no longer lived in the village. Like so many they had joined the armed struggle-out of conviction or under duress. Many of them never returned. I had been studying what I thought was a development institution, but I slowly came to realize that I was exploring an institution that essentially served as an outreach channel of the LTTE to police the community and recruit cadres by proxy.

\footnotetext{
${ }^{31}$ For interesting parallels, see Shah's work on Adivasis and alcohol in relation to the Maoist movement in eastern India: Alpa Shah (2011) 'Alcoholics Anonymous: The Maoist movement in Jharkhand, India', Modern Asian Studies, 45 (5), pp. 10951117 . Similarities include the civilizational narrative of bringing about a pure and equitable society, in which the LTTE's alcohol ban was steeped, and the caste and class dimension of customs around alcohol.
} 
I started asking about the pre-war history of public authority in the village. As elsewhere in Sri Lanka, the community used to have a village leader ('ur talaivar') who enjoyed a significant amount of authority. 'The ur talaivar was proposed from the people,' one man explained. 'But he was powerful. If he would say something, the people would listen.' Under the auspices of the government, this form of village leadership then reincarnated into the RDS. Much in line with Brow's analysis of Kukulewa, it became a clearing house for state-society interaction, most saliently the provision of development resources combined with enhanced state oversight of the community. The RDSs connect to the base of the state's institutional pyramid: the village level officers now known as grama niladaris (GN). The creation of RDSs was part of a larger process of governmentalizing society. They could be thought of as a technology of power, to use a Foucauldian phrase.

The case of Adivasipuram underlines, however, that the RDS comprises dual use technology. It was created as an outreach mechanism of the Sri Lankan state, but was then redeployed to draw people into the orbit of the LTTE's rival state project. Like so many institutions in northeastern Sri Lanka, Adivasipuram's RDS had to sustain itself in a landscape of two rival sovereign claims. One of the wartime RDS leaders explained to me in 2010: 'The RDS had two lords. They come under the government, but the LTTE takes overall control. The LTTE would not involve themselves with the details. If there was a construction contract, normally some people from outside would come with heavy equipment. If the RDS got the contract under LTTE rule, all that work would come under the LTTE. Normally if an RDS gets a contract, they can implement immediately, but we had to first discuss with the LTTE.'

The RDS was thus firmly under LTTE control, but at the same time, its ties with the Sri Lankan state were never severed. Government officers continued to engage with the RDS as a legitimate outreach channel to the community and the LTTE condoned this, though it was simultaneously fighting a full-blown insurgency against the same government. The institutional boundaries between the spheres of the government and the LTTE were thus rather more blurred than a simple categorization of sovereign state versus insurgency would suggest. As an established community platform for channelling development benefits, the RDS provided the LTTE with a useful proxy to attract resources from the state or non-governmental aid agencies. This enabled the provision of minimal welfare to the population under its tutelage-without having to spend any of its own resources- 
and an opportunity for skimming off some tax. The government in turn, continued with this practice, because stopping it would have amounted to conceding its sovereign claim of providing for all its citizens. Completely disengaging from all institutions in LTTEcontrolled territory would effectively have been an endorsement of a de facto Tamil Eelam.

For civil servants in eastern Sri Lanka-many of whom were Tamilthis elbowing for rulership obviously provided a challenge. ${ }^{32}$ On the one hand, there were military restrictions on anything that entered the LTTE-controlled area, and deep-seated suspicion of where the true loyalties of Tamil bureaucrats lay. On the other hand, Tamil civil servants were under pressure from the LTTE to stretch the boundaries of the possible, and many of them felt a need to provide for people living in the LTTE-controlled area, as these were typically the most destitute communities. Publicly engaging with the LTTE was dangerous though, and LTTE priorities were not what got the cogs of the bureaucratic hierarchy moving. This is where the RDS re-enters our story. It provided a work-around for civil servants who were confronted with incompatible forces. After all, a message from the RDS (even when prompted or censured by the LTTE) stood as a legitimate voice of the people, which was compatible with the trappings of bureaucratic rule. Reference to the 'grassroots'-deployed by civil servants to denote the ensemble of village level officers (like the GN) and village level institutions (like the RDS) — was thus not simply about the end point of the state distribution framework; it was in fact a central legitimizing tactic for engagement with areas and people under LTTE control.

One of the former administrators of the area around Adivasipuram (the divisional secretary, DS) explained that all small development projects were to be implemented through an RDS, as per standard government policy. 'I would collect proposals from all the RDSs. They would present them at a meeting with me, the secretary and the director of planning and we would decide. The RDS is elected by the people and they inform the DS.' But surely, I asked him, an RDS in the LTTE-controlled area would have to coordinate with the LTTE

${ }^{32} \mathrm{Klem}$, 'In the eye of the storm', pp. 705-709. There are interesting parallels to the plight and coping mechanisms of Nepal's civil servants during the Maoist insurgency. Byrne, "From our side"; Sarah Byrne and Gitta Shrestha (2014) "A compromising consensus? Legitimising local government in post-conflict Nepal', International Development Planning Review, 36 (4), pp. 434-453; Nightingale et al., 'Fragmented public authority'. 
before proposing anything? He paused, clearly a little reluctant to explain this part of the arrangement, and then said: 'They would not want to propose something that could not be done.' Other respondents were more candid. Most grassroots officers are from the community in which they work, another civil servant explained: 'They will have to work with the LTTE. If we asked for a proposal from them, everyone knew, what we would get was the LTTE's proposal. The civil service would work like that.' The insurgents were particularly interested in funds for construction, one of his colleagues added. In some cases, wells or roads would be built and the LTTE would take control over that. 'The work was done, but they would keep some money. Officially, it would go through the RDS.'

The case of Adivasipuram thus illustrates how a fairly straightforward village development institution like the RDS becomes quite a bit more interesting when it finds itself in the interstices of two competing sovereign frameworks. Let us sum up our main observations before proceeding to our second case study. First, the RDS was originally designed as an outreach channel of the state (much in line with Brow's work on the Veddahs of Kukulewa), but during the war the LTTE co-opted this institution to further its own, contrary state project. The movement successfully brought the RDS under its reign and used it as a surveillance and mobilization mechanism in the community. Secondly, and contrary to the idea that sovereign rule is constructed on clearly demarcated boundaries, the RDS straddled the state-LTTE divide. It continued to connect with the government hierarchy, despite being under LTTE rule. This enabled the LTTE to tap into state resources, and it enabled the government to hold up-at least nominally-its sovereign claim of reaching out to all its citizens. For Tamil civil servants, the RDS became a convenient framework through which to engage with LTTE-controlled areas, without overtly engaging with the LTTE itself. Neither of the two competing sovereign formations thus enforced exclusive loyalty and the RDS in fact served as a kind of 'shatter zone' between the state and the insurgency. Keeping the lines blurred served the interests of both sides. Sovereign encroachment by the LTTE thus comprised a number of apparent paradoxes. It involved assuming hegemony while conniving with practices that subverted that hegemony, and redrawing boundaries, while preserving some level of permeability. This meant actively fighting the institutional hierarchy of the sovereign contender-the Sri Lankan state-while being parasitic on some of its institutions. And it involved a hybrid rendering of Adivasipuram's public, who were 
PUBLIC AUTHORITY UNDER SOVEREIGN ENGROAGHMENT 8OI incorporated into an aspiring Tamil nation without completely erasing their status as citizens of a Sri Lankan welfare state.

\section{Case study 2: Hindu temple politics in Mukkuvarpattu}

Our second case study, a village we will call Mukkuvarpattu, was situated in a very similar political landscape. It came under LTTE control more or less without interruption from the early $1990 \mathrm{~s}$ until the mid-2ooos. There are also some relevant differences. Mukkuvarpattu is a larger settlement and, unlike Adivasipuram above, it has a very long history: the basic layout of the village-the main roads, the temples, the plots of well-established families-goes back many generations. Like so many Tamil villages in eastern Sri Lanka, Mukkuvarpattu's livelihood revolves around paddy cultivation, though the adjacent lagoon provides supplementary income for some. In terms of social organization, the village is organized on the basis of caste. The cultivator castes-Vellala and Mukkuvar-are at the top of the hierarchy, and which of the two dominates is a matter of ongoing struggle. These are followed by middle castes, like the Tattar (goldsmiths), and supposedly lower service castes. They in turn are made up of kudis (matrilineal clans). While this system has been subject to some erosion in the east of the country, it continues to play an important role, particularly in relation to Hindu temples. The boards of these temples follow kudi stratifications and temple festivals ritually dramatize the associated cultural pecking orders, with particular rights, roles, times, and places allocated to different groups. The social hierarchy that emanates from the temples, while not static or uncontested, is pivotal to questions of social order and authority within the community. The question of how a sovereign encroacher like the LTTE grappled with temples is thus not simply a matter of religious conduct, it touches on centrally important aspects of the public sphere in a village like Mukkuvarpattu.

Before we explore the manifestation of Hindu temple authority under LTTE rule in Mukkuvarpattu, let us briefly discuss some of the broader contentions with regard to temples, politics, and conflict. The relationship between religion and politics presents a persistent challenge to contemporary literature on religiosity. While there is merit in the idea that religion and politics represent fundamentally different-even incompatible-dimensions of society, there is clearly a risk of buying into an overly secularized perspective that ushers 
religion into a private, apolitical sphere. ${ }^{33}$ The politics of honour that characterizes South Asian Hindu temples provides a useful entry point into this debate. This politics pivots on questions of the rights and duties of temple management and religious conduct, but which often connect to a much wider set of issues. Very much in line with Gilmartin's notion of the public sphere, Hindu temples can thus usefully be thought of as a zone of encounter where collective subjectivities, forms of authority, wider political alignments, and connections to the state are worked out. A strict conceptual divide between religion and politics is unhelpful to fathom the role of these temples, because so much of what happens cannot be classified as purely religious or purely political, and if such a demarcation emerges in clear form, it is typically invoked for tactical purposes.

Similarly, public authority mustered within the context of these temples cannot be classified along stern dichotomies of religious/political or worldly/spiritual. Mattison Mines' work on individuality and collectivity in Chennai, Tamil Nadu, illustratively details the intricate connections between temples, authority figures, and community. Boundaries and institutions yield to the authority projects of 'big men'. The individuality of these caste leaders, temple trustees, and community benefactors is expressed in collectivities. 'Without leaders, there is no community; without a community, there are no leaders,' Mattison concludes. ${ }^{34}$ Consistent with Gilmartin's perspective discussed above, social norms and boundaries are reworked in the public sphere that is the temple. Larger political struggles enter this zone of encounter in filtered ways. The temple is presented as a religious space that defies the dirty and divisive world of politics, but at the same time it provides a platform for struggles over key political issues under redefined terms. And as such, temples have in fact been quite an important space for conflicts and political transitions throughout South Asia's history. ${ }^{35}$

${ }^{33}$ Clifford Geertz (1973) The interpretation of culture. New York: Basic Books; Asad, Genealogies of religion; Spencer et al., Checkpoint, temples, church and mosque; Sax, 'Conquering the quarters'.

${ }^{34}$ Mattison Mines (1994) Public faces, private voices: Community and individuality in South India. Berkeley: University of California Press, p. 65 .

${ }^{35}$ Arjun Appadurai (1981) Worship and conflict under colonial rule. Cambridge: Cambridge University Press; Chris J. Fuller (2003) The renewal of the priesthood: Modernity and traditionalism in a South Indian temple. Princeton: Princeton University Press; Dennis McGilvray (2008) Crucible of conflict: Tamil and Muslim society on the east coast of Sri Lanka. Durham: Duke University Press; Diane P. Mines (2005) Fierce 
PUBLIG AUTHORITY UNDER SOVEREIGN ENGROAGHMENT 803

The nature and significance of the temple space depends on the kind of temple. In a nutshell, there are three types of Hindu temples in Sri Lanka. First, there are family-owned temples, which are typically tiny shrines in a family compound. Second, are the village temples that are public spaces and usually involve several castes, but which do not attract many people from beyond the local constituency. Included here are Amman temples which have gained prominence in recent decades. Dedicated to the mother goddess Amma and known for their oracles, they attract a particularly heterogeneous crowd of worshipperscutting through boundaries of caste and even of ethnicity and religion. And thirdly, there are the larger temples, which attract people from the whole region or even beyond, particularly during festivals. These include the so-called national ('thesam') temples, which are very wellestablished, with large temple structures and an elaborate and fiercely hierarchical caste arrangement. ${ }^{36}$

Mark Whitaker's thorough study of eastern Sri Lanka's 'thesam' temples (Mandur's Sri Kantasvami Kovil in particular) is an essential reference point with regard to the authority of Sri Lankan Hindu temples. ${ }^{37}$ His analysis shows how the independent political character of these temples, based on caste and the politics of honour, largely withstood the forces of colonialism and post-colonial politics. The $k u d i$-based system outlived a sequence of political transitions. At the same time, Hindu temples provided a platform to articulate some of the struggles associated with these wider politics. They thus comprised a zone of encounter where collective identities were crafted and reframed, and discontents-for example, about casterelated injustices—were expressed. Bryan Pfaffenberger highlights the significance of attempts to overcome these caste differences in

gods: Inequality, ritual, and the politics of dignity in a South Indian village. Bloomington: Indiana University Press; Mines, Public faces, private voices; S. Theyvanayagam (2006) 'Tantonrisvaram, Kokkatticcolai', in S. Pathmanathan (ed.) Hindu temples of Sri Lanka. Colombo: Kumaran Book House, pp. 279-304; Van der Veer, Imperial encounters; Peter van der Veer (1999) Nation and religion: Perspectives on Europe and Asia. Princeton: Princeton University Press.

${ }^{36}$ Maunaguru and Spencer, 'Tigers, temples'.

${ }^{37}$ Mark Whitaker (1999) Amiable incoherence: Manipulating histories and modernities in a Batticaloa Hindu temple. Amsterdam: VU University Press; Mark Whitaker (1999) 'Tigers and temples: The politics of nationalist and non-modern violence in Sri Lanka', in Siri Gamage and I. B. Watson (eds) Conflict and community in contemporary Sri Lanka: 'Pearl of the East' or the 'Island of Tears?' Colombo: Vijitha Yapa, pp. 183-196. 
relation to the emergence of Tamil nationalism. ${ }^{38}$ In its project to subsume all Tamils into a larger nation-to-be, the LTTE (and most other Tamil militant movements) strongly repudiated caste. Whitaker's study suggests, though, that this repudiation was far from effectual. Caste arrangement persisted, if sometimes in a more subdued fashion, and the caste-based foundations of Hindu temples proved to be as enduring under conditions of war as they had been under colonialism. Whitaker thus posits that the politics of status and position around Hindu temples occupied a space that was distinct from the space of Tamil nationalism and ethnic politics. ${ }^{39}$ This idea of temples as separate yet connected spaces does not just apply to the persistence of caste-based temple politics, but also to the fact that Hindu shrines became important places of solace and healing. Amman temples in particular were seen as a setting of seclusion and relative safety, as Patricia Lawrence's work illustrates. ${ }^{40}$ People turned to the oracles of Amman temples in large numbers to present their loss and grief, to contact kin who had died or disappeared, to heal the wounds of war, and to seek advice in solving their problems. In a way, these oracles enacted a kind of public authority in a space demarcated from the repressive political climate of the war. The central quality of these Amman temples was thus to be a public space outside the conflict; at the same time, they represented a form of novel inter-group religiosity that was a direct result of the war. ${ }^{41}$

In short, Hindu temples present a public sphere that is distinct yet connected. They evade and withstand some of the direct forces

${ }^{38}$ This is particularly clear in his work on the temple entry movement in northern Sri Lanka in the late 1960 . Hindu temples became a centrally important arena for contentions around caste and power, when so-called low-caste members struggled for their rights to enter the temple. Bryan Pfaffenberger (1982) Caste in Tamil culture: The religious foundation of Sudra domination in Tamil Sri Lanka. New York: Syracuse University Press; B. Pfaffenberger (1990) 'The political construction of defensive nationalism: The 1968 temple-entry crisis in northern Sri Lanka', Journal of Asian Studies, 49 (1), pp. $78-96$.

${ }^{39}$ Whitaker, Amiable incoherence. See also: McGilvray, Crucible of conflict.

${ }^{40}$ Patricia Lawrence (1999) 'The changing Amman: Notes on the injury of war in Eastern Sri Lanka', in Gamage and Watson (eds) Conflict and community in contemporary Sri Lanka, pp. 197-2 15; P. Lawrence (2000) 'Violence, suffering, Amman: The work of oracles in Sri Lanka's eastern war zone', in Veena Das, Arthur Kleinman, Mamphela Ramphele and Pamela Reynolds (eds) Violence and subjectivity. Berkeley: University of California Press, pp. 171-204.

${ }^{41}$ In eastern Sri Lanka the role of spiritual authority under conditions of war varied significantly across the religious landscape. See Spencer et al., Checkpoint, temple, church and mosque. 
PUBLIG AUTHORITY UNDER SOVEREIGN ENGROAGHMENT 805 of politics and state governance, but also comprise a public sphere where existential issues with political ramifications are worked out. How then, did the LTTE engage with this public sphere and the forms of organization and authority that operate within it?

When I (Sidharthan Maunaguru being the 'I' in this second case study) commenced fieldwork in Mukkuvarpattu, it soon became clear this would result in some rather uneasy encounters. During the war, I was told, a small Amman temple was built and frequented by a kudi of the goldsmith caste. It was located within the complexes of a large and powerful temple. The Amma goddess of the temple gained a powerful status. Soon, it was no longer just the goldsmith caste of the village who came to worship her. Other people from the village and beyond flocked to the shrine. The priest of the temple-the only child of a family from the regional centre of Batticaloa-also belonged to the goldsmith caste. He explained to me that he had met a saint when he was still very young and had been given enlightenment, thus receiving a special power to be a priest to the goddess. He started as the priest in his family temple, near Batticaloa town, but when he married a woman from Mukkuvarpattu he moved to her village, as is customary. He was asked to be the priest at the Amman temple and he quickly became known as a charismatic leader. He was a good orator and his voice was a significant one in the conduct of village activities. Conflict emerged within the goldsmith caste over temple management issues, particularly regarding the rights surrounding the temple festival, but also over questions of resources and construction. In the ensuing debates, the authority of the priest was challenged by people who wanted a larger role in the management of the temple.

In time, the conflict escalated. The people challenging the priest requested the LTTE to intervene and settle the matter. At the time, Mukkuvarpattu was firmly within LTTE-controlled territory. As was the case in Adivasipuram above, the movement ran its own police stations and courts in pursuit of its sovereign objectives. It levied taxes and recruited cadres from the community. While it was obvious that the LTTE ruled Mukkuvarpattu, its ability to settle temple affairs was not so clear. In order to resolve the problem, the LTTE set up a committee. This body was to hear the concerns of both sides and find a solution to the problem, but it was unable to resolve the matter. This intervention only amplified the conflict, I was told. This not only left the temple management in a lurch, it also controverted the LTTE's ability to endorse or refute authority in the village and publicly placed in doubt the legitimacy of the LTTE's committee. The priest in fact 
openly challenged the committee set up by the LTTE. He argued that it could not intervene in temple activities and that the authority of the deity-the mother goddess Amma-overruled that of the LTTE. He publicly stated that he would only act in line with the deity's wishes.

The LTTE saw no alternative but to arrest the priest. He was put in an LTTE prison and beaten. But then, he told me, the tide turned against the LTTE. Within three weeks of his arrest, the LTTE faced major military losses. Government forces completed their conquest of the eastern region, a major turning point in the war and a prelude to the LTTE's total defeat in the north two years later. As the movement retreated from the east, the priest walked out of his jail. At the end of the day, Amma had shown her supreme power, he said. She had punished the LTTE, because it had wrongly punished her devotee for acts that she had warranted. He reclaimed his authority in the name of the goddess and the temple.

But that did not stop the others from disputing his authority. In the aftermath of the LTTE's defeat, the dispute continued. Those challenging the priest took the matter to a state court, where the legitimacy, rights, and legality of the priest's authority continue to be debated. To some extent, state courts thus face the same predicament as the LTTE's committee: they are drawn into the conflicts of temple politics and are often unable to resolve them. Confronted with arguments that are incompatible with their proceedings, in the process their legitimacy as a forum is called into question.

The resistance of the priest may seem like a small force in the pandemonium of civil war, but such subtle forms of recalcitrant authority in the temple arena comprised a challenge to the LTTE unheard of in other walks of life. In a situation where there was a significant amount of friction, the movement's ability to confer authority through its committee was directly opposed.

There were several other temple-related conflicts in Mukkuvarpattu during the war. As I have described elsewhere in some detail, ${ }^{42}$ there was another case where the local LTTE leader tried to put an end to caste-based conflicts by changing the composition of the temple management board. The priests and the board members who were sidelined did not directly oppose this bold move, but they refused to take part in the prescribed activities during the festivals, thus undercutting the authority of the new temple board and challenging

\footnotetext{
${ }^{42}$ Maunaguru, 'Vulnerable sovereignty'.
} 
PUBLIC AUTHORITY UNDER SOVEREIGN ENGROAGHMENT 807 the LTTE's hegemony. Eventually, the LTTE gave in. It washed its hands of the case and the previous temple board resumed its duties.

There are many examples of temple boards resisting LTTE interference in smaller or bigger ways. Attempts by the insurgents to curb caste politics and abolish caste-based entry rights were met with passive resistance. And there are examples of Hindu oracles propagating narratives of the conflict-and predicting solutions to itin ways that challenged the LTTE script. ${ }^{43}$ The movement's sovereign encroachment thus came up against some pushback when it sought to rein in the authority of Hindu priests and the institutional structures of Hindu temples. As a public sphere, Hindu temples did not simply yield to LTTE supremacy. Rather, we see an encounter between the insurgent sovereign project, some very well-entrenched social structures, and adaptable forms of public authority.

In this encounter, the public is rendered in different ways: as Tamil subjects, as a village community, as a religious collective, and as a stratification of caste and kudi. Associated boundaries are reworked: between the public and private, between the political and religious, and between a space of conflict ruled by the LTTE and a space outside that conflict where LTTE rule was defied. In this encounter, temple leaders and constituencies did not subvert the LTTE's sovereign project at large, nor did they intervene in the ethno-political conflict per se, as did other religious leaders. ${ }^{44}$ Instead, the Hindu leaders I have discussed, articulated their public authority by intervening in templerelated issues with reference to a divine power that the LTTE could not subjugate. Their resistance did not comprise direct confrontation, but involved small agitations, dissonant voices, legitimized through deities and warnings of divine punishment. And in doing so, they reworked their own public authority and they indirectly challenged the LTTE.

\section{Sovereign encroachment and the variance of authority}

The case study of Adivasipuram describes a rural development society, which was co-opted by the LTTE to rule the village and which

\footnotetext{
${ }^{43}$ Ibid.

${ }^{44}$ Mosque federations and Catholic priests are the two most obvious examples of religious leadership that took on very visible roles and engaged much more directly with the ethno-political conflict itself. Spencer et al., Checkpoint, temple, church and mosque.
} 
came to straddle the boundary between the LTTE and the state. The case study of Mukkuvarpattu describes the management board and priest of a Hindu temple, who defied LTTE attempts to settle temple-related conflicts. This final section discusses the differences and commonalities between the two case studies with regard to public authority and sovereign encroachment.

Both cases display the dynamics around the sovereign encroachment of the LTTE. In pursuit of its aspiration to establish a separate state, the movement started acting like a state. It created an apparatus of state-like institutions and it manifested itself as a sovereign formation, both steeped in society and elevated above it. In doing so it sought to establish hegemony over all other forms of authority in Tamil society. The movement is well known for its ruthless eradication of rival militias and the silencing of dissonant voices: many Tamil authority figures-politicians, lawyers, school principals, and so onwere intimidated, punished, chased away, or killed for their differences with the LTTE. ${ }^{45}$ The material presented in this article complements this overall picture with insights into the ways in which the LTTE tried to establish its sovereignty by bringing village-level public authority under its supremacy. In both of our case studies, the LTTE manifested itself as sovereign in the sense that it prevailed over society at large with a violent disciplinary regime, through which it endorsed, redefined, or curbed other forms of public authority.

Under closer scrutiny, however, the situation was not so clearcut. In both villages, LTTE attempts to rule the public sphere were characterized by blurred boundaries and forms of compromise. The RDS in Adivasipuram continued to connect with the Sri Lankan state, and while this may have brought the LTTE the tactical advantage of leveraging a trickle of state resources, it also controverted the underlying logic of Tamil Eelam. It left intact the rendering of the villagers as Sri Lankan citizens catered for by the movement's sovereign contender, the Sri Lankan state. And in Mukkuvarpattu, authority figures from the Hindu temple challenged LTTE attempts to adjudicate in an ongoing temple conflict. The former upheld an institutional space that defied the sovereign power of the insurgents. In both cases, the LTTE intervened in the public sphere-the zone of encounter where authority and renderings of the public are worked out. In neither case do we see complete imposition. LTTE

\footnotetext{
${ }^{45}$ Rajan Hoole (2015) Palmyra fallen: From Rajani to war's end. Jaffna: University Teacher's for Human Rights (Jaffna); Thiranagama, In my mother's house.
} 
PUBLIG AUTHORITY UNDER SOVEREIGN ENGROAGHMENT 809 rule was contingent and compromised in the process of sovereign encroachment.

There are also clear differences. Most saliently, the movement had a much firmer grip on the RDS than on the temple management. This brings us back to the basic puzzle of the comparison between the cases: why is it that the Hindu temple leadership in Mukkuvarpattu could engage in small forms of resistance, while the leaders of the development society in Adivasipuram were directly ruled by the LTTE? Apart from some important contextual differences between the two villages, ${ }^{46}$ the key difference lies in the underpinnings of authority in the two village bodies. Because of the different natures of an RDS and a Hindu temple, we see more friction around the LTTE's sovereign encroachment in Mukkuvarpattu than in Adivasipuram. The two represent a different kind of public sphere, and because of that, both the nature of public authority and the dynamics around defining the public are different.

An RDS is a government invention. It was created in villages throughout Sri Lanka to act as an interface between the village and the state. It provides a platform to perform unity and it is a clearing house for state patronage. It is subject to the whims and changes of politics, both internally when alliances form and RDS leaders are elected, and in relation to party politics when competing politicians try to strong-arm the electorate. The significance of these struggles ultimately pivots on the ability to access the state. An RDS represents a public sphere where the invocation of village community as the public and the crafting of authority in their name take place in relation to the categories and resources of the welfare state.

When the LTTE absorbed the Adivasipuram RDS into its system of rule, it followed a similar pattern. The movement supplanted the state and redeployed the RDS as an interface between the community and the sovereign project of Tamil Eelam. And it interfered with the flow of patronage in order to leverage legitimacy. This involved crucial changes-not least because the RDS became an outreach channel for LTTE surveillance and recruitment. But the basic role of the RDS as an interface between the sovereign order and the village did

\footnotetext{
${ }^{46}$ Adivasipuram is a small Veddah village of poor labourers, which was only recently settled. It does not have the elaborate caste and kudi structures that we find in Mukkuvarpattu, a more significant village with a complex arrangement around temples and paddy cultivation. This contrast (simply put, a dichotomy between erstwhile forest dwellers and a hierarchical community of rice cultivators) arguably accentuates the contrast between the two village bodies that we are analysing.
} 
not change. The public authority of an RDS pivots on development, more specifically on the provision of development resources by a state benefactor. When the nature of development and of the state benefactor changed, the RDS adapted. Its authority was contingent on the ability to cope with the competing sovereign forces of the government and the LTTE. An RDS is not deployed against the frameworks from which it derives its legitimacy, and thus in this case it ended up occupying the middle, straddling the boundaries between the two state projects.

Hindu temples are a different kind of public sphere, and the constitution of the public and of public authority are concurrently different. Its public is characterized by historical stratifications of caste and kudi. These divisions are a continuous source of struggle around positions, rights, and honours. Some of the associated hierarchies are quite rigid and there may be periods of relative equilibrium, but the public is never unitary, it is always somewhat volatile due to contending projects of acknowledgement. Public authority is implicated by these struggles, but, unlike the RDS where access to the state is the ultimate referent, priestly authority is derived from deities. There are connections to the state, through official endorsements or conflicts that escalate to state courts, but the ultimate power to adjudicate is not attributed to the sovereign state, but to the gods of the temple. ${ }^{47}$ As we have seen above, the temple space is thus a platform for larger political conflicts over rights and justice, but it simultaneously tends to defy direct political interference. The temple is connected to the state and its politics, yet is distinct from it. In this regard the RDS is very different: it is a direct extension of the state and its politics.

In view of these differences, it makes sense that the LTTE's project of sovereign rule encountered some friction in Mukkuvarpattu. The authority of the priest and other temple figures is sourced in a world that the LTTE could not control: deities and oracles were not amenable to the movement's discipline. Similarly, the renderings of the public were not entirely compatible with the separatist cause. The fragmented nature of the temple constituency, with its continuous struggles over the honours and duties of sub-groups, sits uneasily with the singular subjectivity of 'the Tamil people', which was so central to the LTTE's discursive outlook.

\footnotetext{
${ }^{47}$ For more detail, see Maunaguru, 'Sovereign deities'.
} 
PUBLIC AUTHORITY UNDER SOVEREIGN ENGROAGHMENT 811

It is true, of course, that RDSs are not necessarily beacons of public unity either. Brow's work on the Kukulewa bears this out: the creation of the RDS went hand-in-hand with the penetration of divisive party politics. Many RDSs thrive on factionalism, competing family dynasties, and fierce debate. As in any public sphere, authority is questioned and contested. But party-political divisions of the public could be trumped to some extent by Tamil nationalist politics, be it in parliament (where the Tamil National Alliance emerged as an LTTE appendage sustained by a Tamil block vote) or at the village level, where the LTTE subsumed all ideological divisions under the Tamil cause.

In contrast, the LTTE could not trump the politics of honour around caste and kudi stratifications. And because of that, the public sphere of the temple was not one that the movement could domesticate. When it imposed itself by exercising its sovereign power and arrested the priest, it did not dissolve the conflicts of the temple, it dislocated them. Disagreement and resistance were rearticulated in the language of religion, rights and honour, and members who refused to perform their duties in publics and festivals.

The multifarious and conflictual nature of the temple constituency thus confronted the LTTE with a particularly pronounced version of what Gilmartin and others have called the 'sovereign conundrum'. A sovereign figure must simultaneously be part of the community of the ruled, while also being elevated above it. Sovereign rule must be engaged with society's divisions and conflict, and provide an arena for contestation, but it must also stand apart from society to project an image of unity. In the goldsmith temple of Mukkuvarpattu, the LTTE grappled with this paradox and found itself unable to resolve it. This tension became particularly acute because of the forceful conduct of the LTTE. But the basic dynamic is in fact very common in the interaction between temples and the state. As mentioned, state courts face similar difficulties in grappling with conflicts over temple festivals and resources like the one in Mukkuvarpattu. There are accounts of cases that rumble on without resolution for over 6o years, ${ }^{48}$ and colonial accounts are littered with unsuccessful state attempts to manage temple affairs. ${ }^{49}$ The Sri Lankan state may be a recognized

\footnotetext{
${ }^{48}$ Whitaker, Amiable incoherence.

${ }^{49}$ Appadurai, Worship and conflict. Appadurai points to the significance of colonial government replacing pre-colonial kings, who were seen to act on behalf of deities. When colonial authorities sought to manage the temple through legal procedure,
} 
sovereign state, which has successfully defeated its main sovereign challenger, the LTTE, but in the margins of its rule, contentions over the nature of authority and the limitations of sovereign power persist.

\section{Conclusion}

Sovereign rule is not simply imposed, but needs to be worked out in the public sphere. This was true in colonial and post-colonial times in South Asia. And it holds true in contemporary Sri Lanka. The LTTE engaged in a form of sovereign encroachment. Despite all the ruthless violence and the coercive backbone of the insurgency, the separatist struggle did not simply steamroll Tamil society. The aspired sovereign order of Tamil Eelam was compromised by blurred boundaries, competing loyalties, subtle forms of defiance, and spheres beyond its reign. The LTTE controlled large swathes of territory and exercised control over a large population. But within the society that it claimed to rule there were spheres that withstood its supremacy, such as the Hindu temples we have described. And the demarcation of sovereign space was permeable: the RDS straddled the boundary between the sovereign projects of the LTTE and the state. This fuzziness was not a sign of neglect or failure on the part of the insurgents, but part of a deliberate tactic. Sovereign encroachment involves a gradual and sometimes pragmatic process of working out hegemony over pockets of society by experimenting and redrawing boundaries. It is well established that the LTTE acted as a ruthless, coercive movement that deployed its violent capacities to discipline Tamil society and eradicate dissidents, but at the same time its project of sovereign encroachment was partly contingent on the institutional trappings of Tamil society and limits to what was seen to be publicly tenable. ${ }^{50}$

Our comparison of two cases suggests that some public spheres are more resilient to sovereign assertion than others. The RDS came under complete LTTE control. Although it continued to interact with the Sri Lankan state, it did so on the LTTE's terms. The Hindu temple

this created tension between temple politics and the state, resulting in endless court cases.

${ }^{50}$ For a broader discussion on the LTTE's attempt at governance in relation to questions of legitimacy, see Terpstra and Frerks, 'Governance practices and symbolism'. 
PUBLIC AUTHORITY UNDER SOVEREIGN ENGROAGHMENT 813 leadership, however, actively questioned and resisted the committee set up by the LTTE to adjudicate temple conflicts. There is a high degree of historical continuity in this regard. RDSs were set up by the state as clearing houses within the community and they continued in that role under the LTTE. Temple societies have a long history of defying state control, which also continued under the LTTE. We attribute this difference to the nature of both institutions. The RDS is a public sphere that was created as an outreach channel of the state. It derives its authority from its ability to connect the community to external patronage and is thus saturated by political contestation. The LTTE's nationalist project, arguably the island's most powerful form of political contestation, subsequently permeated RDSs. The arrangement changed, but the institution was deployed in line with its original conception. Hindu temples, in contrast, comprise a different kind of public sphere. Their public authority is derived from their ability to draw connections between the community (and its caste and kudi constituents) and the spiritual world of deities. The nature of this arrangement constrained the LTTE's ability to rein in these forms of authority. It involved social categories that touched at the root of the Tamil nation itself and forms of cosmic power that were beyond the grasp of the movement's discipline. Hindu temples comprise a public sphere that is distinct from, yet connected to, political contentions. They defy direct political interference, but they provide a platform for political struggles under redefined terms. These struggles, in turn, may have broader political effects. This was true for struggles over colonial jurisdiction of temples in British India, ${ }^{51}$ it was true for the caste struggle of Sri Lanka's temple entry movement prior to the war, ${ }^{52}$ and it was true for the subtle forms of resistance to LTTE rule during the civil war.

A Hindu temple and an RDS are of course just two quite disparate examples from a much greater variety of public spheres. There are some obvious connections to other articles to this special issue. Several contributions highlight the tenacity of particular forms of public authority in relation to sovereign rule. Public authority does not simply yield to coercive force, it also holds up particular normative repertoires and expectations. Anushay Malik's contribution, for example, shows how the power and legitimacy of a Pakistani working-class leader is steeped in cultural norms. During the turbulent time in early 197 os Lahore, Abdur Rehman's workers' court became a repository

\footnotetext{
${ }^{51}$ Appadurai, Worship and conflict.

${ }^{52}$ Pfaffenberger, 'The political construction'.
} 
for preserving public morals in response to the state's inability to uphold a legitimate order. ${ }^{53}$ Sarah Byrne, in a similar vein, describes how Nepali civil servants stuck to particular societal norms, even as they tried to circumnavigate Maoist rule and state order during the war. Their manoeuvring was not just a survival tactic, it also served to uphold basic principles such as the need to care for poor farmers and the associated enactment of paternalistic duties of highcaste administrators. ${ }^{54}$ Both articles illustrate how public authority is constructed on the basis of norms and expectations that persist even amid the turmoil of revolutionary violence.

This endurance suggests that public authority is tenacious, but not inert. Our case studies illustrate how public authority needs to adapt in order to sustain itself. It is not erased by the sovereign onslaught of civil war, but it is affected by it. We define public authority as a relational form of power with a measure of voluntary compliance, and that still holds true. But as our analysis shows, that relational power is not just shaped by the interaction between public authority figures and their constituencies, but by a wider set of encounters in the public sphere. Interestingly, public authority may derive validity from sovereign endorsement - for example by being situated in the wider institutional architecture of the state. But it derives similar validity from the ability to sustain itself in an environment of contested sovereignty or from the ability to defy sovereign rule. The Adivasipuram RDS leaders retained public authority through their ability to cope with the convoluted landscape of civil war: succumbing to the LTTE, but continuing to connect with state institutions. They maintained part of their relevance thanks to-not despite-the onslaught between the LTTE and the government. The obstinate Hindu priest of the Amman temple in Mukkuvarpattu did not derive authority from sovereign conferral, but from his attempt to challenge the LTTE's sovereign assertion. In sum, public authority may be 'conjugated' with the state, as Lund suggests, ${ }^{55}$ or given credence by the state as the 'great enframer', ${ }^{56}$ but it is not simply a derivative of sovereign order. Rather, it evolves in more contingent ways from encounters in the public sphere. It can be produced through sovereign endorsement or by opposing it; by holding its ground or by adapting.

\footnotetext{
${ }^{53}$ Anushay Malik, 'Public authority and local resistance: Abdur Rehman and the industrial workers of Lahore, 1969-1974' in this special issue.

${ }^{54}$ Byrne, "“From our side".

${ }^{55}$ Lund, 'Twilight institutions', p. 686.

${ }^{56}$ Hansen and Stepputat, States of imagination, p. 27.
} 